\title{
Impact of Soil Health Card Scheme on Paddy Farmers' Income in North Eastern Karnataka
}

\author{
V. Abhishek ${ }^{1 *}$, Jagrati B. Deshmanya ${ }^{1}$, Prabhuling Tevari ${ }^{1}$, \\ G. B. Lokesh ${ }^{1}$, M. V. Ravi ${ }^{2}$ and K. Suresh ${ }^{1}$ \\ ${ }^{1}$ Department of Agricultural Economics, University of Agricultural Sciences, \\ Raichur, 584104, India \\ ${ }^{2}$ Krishi Vigyana Kendra, Gangavathi, University of Agricultural Sciences, \\ Raichur, 584104, India \\ *Corresponding author
}

\section{A B S T R A C T}

\section{Keywords \\ Soil health card, Cost of cultivation, Returns, Benefit cost ratio, Paddy \\ Article Info \\ Accepted: \\ 07 August 2020 Available Online: \\ 10 September 2020}

The present study on economic analysis of soil health cards on production and productivity of major crops was conducted in Karnataka state with the focus on North Eastern Karnataka region. However the study area was confined to Raichur district as it is having the major area under paddy $(21.01 \%)$ growing area in this region. Where in the primary data was collected by interviewing the farmers. A total of 20 Soil health card using farmers and 20 Soil health card non using farmers were selected randomly for the study. The cost of cultivation of paddy was found higher in Soil health card non users (₹ 95,219/ha) than Soil health card users ( $₹ 92307 /$ ha). The yield of paddy was substantially higher in Soil health card using farmers (qtl 75.34/ha) than Soil health card non users (qtl $71.05 / \mathrm{ha}$ ) and B:C ratio was also higher for Soil health card users (1.58) compared to Soil health card non users (1.45). So the Soil health card is an instrumental tool for enhancement of yield and income of paddy farmers

\section{Introduction}

Soils are the resources that support and sustain a huge diversity of life forms on earth with its diverse physical, chemical and biological properties. The health of these dynamic resources is a measure of a complex set of physical, chemical and biological interactions that support healthy plant growth. Unhealthy soils that do not contain enough nutrients to support crop growth need more input, use input inefficiently, give less productivity per unit of input and its productivity potential gets weakened with time (Katyal et al., 2016). Realizing the importance of soils the International Union of Soil Sciences (IUSS) recommended celebrating an international day for soils in the year 2002, to create a global awareness about importance of healthy soils and sustainable management of soil resources. Further, the Food and Agricultural Organization (FAO) conference unanimously endorsed World Soil Day in June 2013 and in December 2013 UN General Assembly designated December 5, 2014 as the first official World Soil Day. FAO also declared the year 2015 as the "International Year of 
Soil" with a theme "Healthy Soils for Healthy Life". India is the third largest producer and consumer of fertilizer in the world, after China and USA. Though there is significant increase in the food grain production in the post green revolution period due to impressive growth in the fertilizer consumption, this has led to the consequences like deterioration of soil structure, wastage of nutrients, destruction of soil microorganisms and scorching of plants at the extreme cases. A combination of factors such as intensive cultivation of crops, differential pricing of fertilizers and subsidy, might have contributed to excessive use of fertilizers by the farmers. At the same time, it is reported that many parts of India shown deficiency of not only primary nutrients $(\mathrm{N}, \mathrm{P}, \mathrm{K})$ but also secondary (Sulphur, Calcium and Magnesium) and micro nutrients (Boron, Zinc, Copper and Iron).

Government of India had undertaken initiatives to ameliorate the situation and encourage the farmers for balanced use of fertilizers by initiating a national level effort to practice a healthy agriculture by sustaining the soil resources through the Soil Health Management component under National Mission for Sustainable Agriculture (NMSA) in the year 2014. The implementing agency of SHM programme is Integrated Nutrient Management (INM) Division of Department of Agriculture and Cooperation, Ministry of Agriculture and Farmers Welfare, Government of India. The SHM emphasized promoting location as well as crop specific sustainable soil health management, creating and linking soil fertility maps, judicious application of fertilizers and organic farming practices. Soil Health Card is an important component of the SHM with an aim to issue soil health cards to all farmers of the country in every three years (GoI, 2016). The Government of India launched Soil Health Cards Scheme nation-wide on $19^{\text {th }}$ February,
2015. The Department of Agriculture of different states are the main executive bodies to implement the scheme in their respective states.

A Soil Health Card (SHC) is a printed card given to a farmer that contains the status of various plant nutrients available in his/her soil (soil health indicators) as well as the dosage of different fertilizers for the major crops grown in his/her farmland based on the soil test results. The Soil health card presently depicts the status of 12 essential parameters like $\mathrm{pH}, \mathrm{EC}$, Organic carbon, available Nitrogen (N), Phosphorus (P), Potassium (K), Sulphur (S), Iron (Fe), Manganese (Mn), Zinc $(\mathrm{Zn})$, Copper $(\mathrm{Cu})$, and Boron $(\mathrm{B})$ and along with the farmer's personal details such as Aadhaar number and plot details. Acharya and Srivastava (2017) commented about the benefit of soil health card scheme as the adoption of soil health card based fertilizer recommendation is expected to economize on fertilizer use in the country by reducing the fertilizer consumption in the areas where soil fertility is build up and increasing its use in the areas where it is required. This would ensure an increased productivity on sustainable basis and also reduce the financial burden on government towards import of fertilizer(s) and fertilizer raw material.

\section{Materials and Methods}

\section{Study area}

Raichur district lies between $15^{\circ} 09^{\prime}$ and $16^{0}$ 34' North latitude and $75^{\circ} 46^{\prime}$ and $77^{\circ} 35^{\prime}$ East longitude. The general slope of the district is from the north-west towards the south-east and its average height above mean sea-level is 1,311 feet. As per the census 2011, the climate of the district is characterized by dryness for the major part of the year and very hot summer. The average rainfall of the district is about $621 \mathrm{~mm}$. The 
low and highly variable rainfall renders the district liable to drought, 80 per cent of the source of irrigation is by canals. Two types of soil can be found in this area, the black cotton soil in the west and red soil in the rest of the places.

\section{Sampling and data collection}

The study was conducted in Raichur district of North Eastern Karnataka region, which is purposively selected in consonance with the objectives of the study. Raichur is one of the important and major growing districts in North Eastern Karnataka region. Out of five talukas in the district, Raichur and Sindhanur were selected for the study on the basis of highest soil health card distribution in the district.

\section{Analytical tools and techniques employed}

To fulfil the specific objective of the study, based on nature and extent of the data, collected data was analyzed with help of tabular analysis, averages, percentages, paired sample ' $\mathrm{t}$ ' test.

\section{Paired sample ' $t$ ' test}

For the selected crops viz; paddy and cotton the difference between with and without Soil Health Card farming in respect of yield per hectare was tested by using paired ' $t$ ' test.

$$
\mathrm{t}=\frac{\overline{\mathrm{x}_{1}-\overline{\mathrm{x}_{2}}}}{\mathrm{~S}} \sqrt{\frac{\mathrm{n}_{1} \mathrm{n}_{2}}{\mathrm{n}_{1}+\mathrm{n}_{2}}}
$$

Where,

$\mathrm{X}_{1}$ and $\mathrm{X}_{2}$ are the means of yield per hectare for SHC users and SHC non-users, respectively, $\mathrm{n}$ is are the number of observations in the two samples and $\mathrm{S}$ is the standard deviation of the difference between two samples

\section{Results and Discussion}

\section{Costs and returns realised by farmers under paddy cultivation}

The per hectare cost of cultivation of paddy was worked out for SHC and SHC non-users and it is presented in Table 2. It was observed that total variable cost for SHC farmers was found to be (Rs. 67,616/ha) which is relatively lower than that of SHC non-users (Rs. 70,595/ha). Similarly total fixed cost in SHC and SHC non-users accounted was Rs. $28069 /$ ha. Out of total variable cost, the cost incurred on human labour constituted a major share $(15.84 \%)$, followed by the cost on fertilizer (11.10\%), FYM (10.83\%), plant protection chemicals $(9.48 \%)$, machine labour $(9.48 \%)$, seed $(5.81 \%)$ and interest on working capital $(5.73 \%)$ which together constituted of 69.59 per cent on total cost. The rental value of the land shares $(27.78 \%)$ of total cost followed by interest on fixed capital (1.24\%), depreciation (1.22\%) and land revenue $(0.17 \%)$ were other fixed cost. The returns structure in paddy production clearly revealed that the gross returns obtained by SHC users was found to be relatively higher (Rs. 1,46,610/ha) than that of SHC non-users (Rs. 1,37,837/ha). Similarly the net returns realized by SHC users (Rs. 53852/ha) which is higher when compared to SHC non-users. The returns per rupee of investment of SHC and SHC non-users were 1.58 and 1.45 respectively. This kind of results might be due to optimum use of resources viz., fertilizer and PPC which will reduce the cost of cultivation in paddy for SHC users and get higher yield than SHC non-users. There may be other reason also such as recommended dose of fertilizer application which would help in avoiding the attack of pest and diseases and it would have been contributed for increase in yield and returns from paddy cultivation. These results are in line with the study conducted on impact 
of Soil Health Card scheme on production, productivity and soil health in Assam by Bardoloi and Das (2017), reported that the average grain yield of the paddy crop for the farmers applied soil test based fertilizer had $32.8 \mathrm{qtl} / \mathrm{ha}$ and that of control farmers had $31.55 \mathrm{qtl} / \mathrm{ha}$ found in their study conducted in Jorhat and Golaghat district of Assam. The results also similar to Singh (2017), stated that the benefit cost ratio of SHC users was 3.68 and SHC non-users was 3.66 in bengalgram production. In their study conducted on chickpea farmers in Bemetara and Mungeli district of Chhattisgarh.

Comparison of crop yield between soil health card and soil health card non-users

The yield obtained per unit area is one of the crucial parameter for economic gain for farmers. An attempt was made to quantify the effect of Soil Health Card on yield of paddy in the study area. The paired ' $t$ ' test is used to find out the effect of Soil Health Card on yield obtained by Soil Health Card users and Soil Health Card non-users. The different parameters related to paired ' $\mathrm{t}$ ' test are presented in Table 3. The results unveil that the mean yield for paddy was found higher for farmers who applied fertilizer as recommended in SHC (75.34 qtl/ha) when compared to SHC non-users (71.05 qtl/ha) in the study area. The yield difference for SHC users and non-users was found statistically significant at 5 per cent level of significance. This might be due to balanced fertilizer use by SHC users. The results are in line with the results obtained by Makadia, 2012), conducted study on regional imbalance and impact of Soil Health Card on fertilizer consumption in Gujarat and suggested that the farmers are advised to use chemical fertilizers based on Soil Health Card recommendation.

\section{Comparative advantage of soil health card users over soil health card non-users in paddy cultivation}

Comparative advantage of soil health card farmers over Soil Health Card non-users farmers of the selected crops in the study area was discussed in Table 4. Revealed that the total cost saved by the Soil Health Card users was Rs. 2912/ha and extra return realized than SHC non-users was Rs. 8323/ha. It is also interesting to note that, the returns per rupee of investment for SHC users was higher with 1.58 compared to SHC non-users 1.45 in paddy production. The indistinguishable result was found with Ramappa (2015), revealed that the average yield of paddy was found more in case of soil test farmers by 8.35 per cent over control farmers in their study conducted on adoption of recommended doses of fertilizer on soil test basis by farmers in Karnataka.

Table.1 Soil Health Card (SHC) distributions in Raichur district

\begin{tabular}{|r|r|r|r|r|}
\hline Sl. No. & Taluk & No. of soil samples & No. of farmers & SHC distributed \\
\hline $\mathbf{1}$ & Lingsugur & 10,085 & 39,407 & 39,402 \\
\hline $\mathbf{2}$ & Devadurga & 14,017 & 36,696 & 36,676 \\
\hline $\mathbf{3}$ & Raichur & 18,314 & 43,970 & 43,950 \\
\hline $\mathbf{4}$ & Manvi & 8,605 & 23,312 & 26,938 \\
\hline $\mathbf{5}$ & Sindhanur & 24,688 & 49,665 & 49,389 \\
\hline & Total No & $\mathbf{6 4 , 7 0 9}$ & $\mathbf{1 , 9 3 , 0 5 0}$ & $\mathbf{1 , 9 6 , 3 5 5}$ \\
\hline
\end{tabular}

Source: Department of Agriculture. Government of Karnataka (2018) 
Table.2 Costs and returns realised by farmers under paddy cultivation (₹/ha)

\begin{tabular}{|c|c|c|c|c|c|}
\hline \multirow{2}{*}{$\begin{array}{l}\text { Sl. } \\
\text { No. }\end{array}$} & \multirow[t]{2}{*}{ Particulars } & \multicolumn{2}{|c|}{ SHC users $(n=20)$} & \multicolumn{2}{|c|}{ SHC non-users $(n=20)$} \\
\hline & & Quantities & Value & Quantities & Value \\
\hline A. & Variable cost & & & & \\
\hline 1 & Seeds $(\mathrm{kg})$ & 68.00 & $\begin{array}{c}5363 \\
(5.81)\end{array}$ & 69.32 & $\begin{array}{c}5467 \\
(5.74)\end{array}$ \\
\hline 2 & Manure (t) & 04.50 & $\begin{array}{c}10000 \\
(10.83)\end{array}$ & 05.69 & $\begin{array}{c}8250 \\
(8.66)\end{array}$ \\
\hline 3 & Fertilizers (kg) & 885.17 & $\begin{array}{c}10250 \\
(11.10)\end{array}$ & 1076.26 & $\begin{array}{l}12500 \\
(8.66)\end{array}$ \\
\hline 4 & Plant protection chemical (Lt) & 08.50 & $\begin{array}{l}8750 \\
(9.48)\end{array}$ & 09.80 & $\begin{array}{c}10500 \\
(11.03)\end{array}$ \\
\hline 5 & Human labour (MD) & 58.50 & $\begin{array}{c}14625 \\
(15.84)\end{array}$ & 61.00 & $\begin{array}{c}15250 \\
(16.02)\end{array}$ \\
\hline 6 & Machine labour (Hr) & 12.50 & $\begin{array}{l}8750 \\
(9.48)\end{array}$ & 12.85 & $\begin{array}{l}9000 \\
(9.45)\end{array}$ \\
\hline 7 & Miscellaneous & & $\begin{array}{c}1209 \\
(1.31)\end{array}$ & & $\begin{array}{c}1209 \\
(1.27)\end{array}$ \\
\hline \multirow[t]{2}{*}{8} & $\begin{array}{l}\text { Interest on working capital(at } 8 \\
\text { per cent per annum) }\end{array}$ & & $\begin{array}{c}5291 \\
(5.73)\end{array}$ & & $\begin{array}{l}4974 \\
(5.22)\end{array}$ \\
\hline & Sub total & & $\begin{array}{c}67616 \\
(69.59)\end{array}$ & & $\begin{array}{c}70595.05 \\
(70.52)\end{array}$ \\
\hline B. & Fixed cost & & & & \\
\hline 1 & Land revenue & & $\begin{array}{c}160 \\
(017)\end{array}$ & & $\begin{array}{c}160 \\
(0.17)\end{array}$ \\
\hline 2 & Depreciation & & $\begin{array}{l}1125 \\
(1.22)\end{array}$ & & $\begin{array}{c}1125 \\
(1.18)\end{array}$ \\
\hline 3 & Rental value & & $\begin{array}{c}25640 \\
(27.78)\end{array}$ & & $\begin{array}{c}25640 \\
(26.93)\end{array}$ \\
\hline \multirow[t]{2}{*}{4} & Interest on fixed capital at $12 \%$ & & $\begin{array}{l}1144.2 \\
(1.24)\end{array}$ & & $\begin{array}{l}1144.2 \\
(1.20)\end{array}$ \\
\hline & Sub total & & $\begin{array}{c}28069 \\
(30.41)\end{array}$ & & $\begin{array}{l}28069 \\
(29.48)\end{array}$ \\
\hline C. & Total Cost (I +II) & & $\begin{array}{c}92307 \\
(100)\end{array}$ & & $\begin{array}{c}95219 \\
(100)\end{array}$ \\
\hline D. & Yield (qtl) & & 75.34 & & 71.05 \\
\hline E. & Gross Returns & & 146160 & & 137837 \\
\hline F. & Net Returns & & 53852 & & 42618 \\
\hline G. & B.C Ratio & & 1.58 & & 1.45 \\
\hline
\end{tabular}

Note: The figures in the parentheses indicate percentage to respective total 
Table.3 Comparison of crop yield between soil health card users and non-users

\begin{tabular}{|c|l|c|c|c|c|}
\hline Crop & \multicolumn{1}{|c|}{ Parameters } & $\begin{array}{c}\text { SHC users } \\
(\mathbf{n = 2 0})\end{array}$ & $\begin{array}{c}\text { SHC non-users } \\
(\mathbf{n = 2 0})\end{array}$ & $\begin{array}{c}\text { Impact } \\
\mathbf{q t} \text { //ha }\end{array}$ & $\begin{array}{c}\text { 't' test } \\
\text { value }\end{array}$ \\
\hline \multirow{2}{*}{ Paddy } & Mean yield(q/ ha) & 75.34 & 71.05 & 4.29 & $4.72 *$ \\
\cline { 2 - 6 } & Standard deviation & 5.92 & 5.05 & & \\
\cline { 2 - 5 } & No. of observations & 20 & 20 & & \\
\hline
\end{tabular}

Note: *Significant at 5 per cent

Table.4 Comparative advantage of SHC users over SHC non-user farmers in paddy cultivation (Rs. /ha)

\begin{tabular}{|c|l|c|c|c|}
\hline Crop & \multicolumn{4}{|c|}{ Particulars } \\
\hline \multirow{3}{*}{ Paddy } & Soil Health Card & Total cost & Gross returns & Net returns \\
\cline { 2 - 5 } & Users $(\mathbf{n = 2 0})$ & 92307 & 146160 & -2912 \\
\cline { 2 - 5 } & Non users $(\mathbf{n = 2 0})$ & 95219 & 137837 & 8323 \\
\hline \multirow{2}{*}{ Net change (Rs.) } & -2912 & 8323 & 11234 \\
\hline
\end{tabular}

Note: (-) indicated reduction in cost

$(+)$ indicated increase in returns

In conclusion the total cost of cultivation for paddy crop was marginally higher in Soil Health Card non-users (Rs. 95,219/ha) compared to Soil Health Card users which was (Rs. 92,307/ha). However, net returns accrued was higher in case of SHC users (Rs. 53,852/ha) than SHC non-users (Rs.42,618/ ha) in paddy cultivation.

The cost on fertilizers and Plant Protection Chemical were (Rs.12500/ha) and (Rs.10500/ha) respectively which was found higher in SHC non-users in contrast, to cost of fertilizer (Rs. 10250/ha) and plant protection chemical (Rs.8750/ha) for SHC users in paddy cultivation. It was found that mean yield per hectare realized by SHC (75.34 $\mathrm{qtl} / \mathrm{ha}$ ) users in paddy cultivation was comparatively higher than SHC non users (71.05 qtl/ha) and significant at 5 per cent level. Hence from the results we have observed a significant impact on production and productivity of paddy crop due to intervention of Soil health card scheme. Further improvisations can be made by bringing Legal bindings for displaying of crop specific recommended dose of fertilizer chart in retail fertilizer shops and create awareness among farmers.

\section{References}

Bordoloi, J. and Das, A. K., 2017, Impact of soil health card scheme on production, productivity and soil health in Assam. Study No.148. Agro-Economic Research Centre for North-East India, Assam Agriculture University, JorhatAssam.

Government of India. 2016, Guidelines for Implementation of Soil Health Management (SHM) component under National Mission for Sustainable Agriculture (NMSA). Integrated Nutrient Management Division of Department of Agriculture \& cooperation, Ministry of Agriculture \& Farmers Welfare.

Katyal, J. C., Chaudhari, S. K., Dwivedi, B. S., Biswas, D. R., Rattan, R. K., and Manjumdar, K. 2016, Soil Health: Concepts, Status and Monitoring. 
Bulletin No.30, Ind. Soc of Soil Sci. New Delhi. 107p.

Makadia, J. J., 2012, Regional imbalance and impact of soil Health Card on Fertilizer consumption in Gujarat. Economic Affairs. 62(1): 61-66.

Ramappa, K. B., and Lavanya, B. T., 2015, Adoption of recommended dose of fertilizers on Soil test basis by farmers in Karnataka. Institute for Social and
Economic Change Bangalore.

Singh, V., 2017, A study on impact of National Food Security Mission (NFSM) on productivity and income among the chickpea beneficiaries in Bemetara and Mungeli district of Chattisgarh. M.Sc.(Agri.) Thesis (unpubl.) Indira Gandhi Krishi Vishwavidyalaya, Chhattisgarh.

\section{How to cite this article:}

Abhishek, V., Jagrati B. Deshmanya, Prabhuling Tevari, G. B. Lokesh, M. V. Ravi and Suresh, K. 2020. Impact of Soil Health Card Scheme on Paddy Farmers' Income in North Eastern Karnataka. Int.J.Curr.Microbiol.App.Sci. 9(09): 786-792.

doi: https://doi.org/10.20546/ijcmas.2020.909.099 